\title{
The Influence Of Perceived Occupational Stress On The Organizational Citizenship Behaviour Of Bankers In Ikeja, Lagos State
}

\author{
Arogundade Odunayo. T \\ Lawal Oladipupo. \\ Department of Behavioural Studies, Redeemer's University, \\ Ede, Osun State, Nigeria
}

doi: 10.19044/esj.2016.v12n17p449 URL:http://dx.doi.org/10.19044/esj.2016.v12n17p449

\begin{abstract}
This study explored the influence of perceived occupational stress on organizational citizenship behaviour among bankers. A simple random sampling technique was used to select three hundred (300) participants $(M=135 ; \mathrm{F}=165)$ from twelve (12) banks in Ikeja, Lagos State, Nigeria. Data for the study were collected using Job Stress Scale (JSS) and Organizational Citizenship behaviour Checklist (OCBC). The data was analysed using Pearson correlation, and t-test. The results revealed that there is no significant difference between the organizational citizenship behaviour of bankers with higher stress levels and that of bankers with lower stress levels. This implies that bankers' reactions to Organizational Citizenship Behaviour (OCB) are not a function of stress levels. The study however confirms an inverse relationship between stress and Organizational citizenship Behaviour. The findings of the study reveal that there is no significant difference between the Organizational Citizenship Behaviour (OCB) of male and female bankers. Finally, the findings reveal that older bankers between age 41 and 50 years expressed higher levels of organizational citizenship behaviour than younger bankers between 31 and 40 years. The implications of these findings substantiate the importance of having organizational psychologists in banks to assess and enhance variables that can promote helping behaviours which is the key to better work outcomes and accomplishment of organizational objectives.
\end{abstract}

Keywords: Organizational Citizenship Behaviour, Perception, Occupational Stress, employees 


\section{Introduction}

Organizational citizenship behaviour is individual behaviour that is discretionary, not directly or explicitly recognized by the formal reward system, and that in the aggregate promotes the effective functioning of the organization (Organ, 1988).

Organizational citizenship behaviour was proposed as a type of job performance, differentiated from conventional job performance or execution on the premise of its relative freedom from situational and ability constraints. This implies that the individual performing the job does not have a great deal of space to vary in performance based on their satisfaction with the context. Conversely, offering an associate some assistance does not necessarily rely on upon expertise in such is not part of the individuals job description, or not normally fixing to a man's expected set of responsibilities that individual might choose not to perform the behaviour at all (Organ, 1988).

Organ (1988) identified five distinct dimensions of OCB which include; Altruism, conscientiousness, civic virtue, courtesy, and sportsmanship. Altruism was defined as discretionary behaviours that have the effect of helping a specific work colleague with an organizationally relevant task or problem. Civic virtue involves staying aware of imperative matters inside of the organization.it is characterized by behaviours that indicate the employee's deep concerns and active interests in the life of the organization (Law, Wong, \& Chen, 2005).Conscientiousness involves consistency and compliance with norms or standards. Conscientiousness consists of behaviours that go well beyond the minimum role requirements of the organization (Law et al., 2005) these behaviours indicate that employees accept and adhere to the rules, regulations and procedures of the organization. Courtesy has been defined as discretionary behaviours that aim at preventing work related conflicts with others. Sportsmanship has been defined as willingness on the part of the employee that signifies the employee's tolerance of less-than-ideal organizational circumstances without complaining and blowing problems out of proportion.

A different perspective on the dimensionality of OCB originated from Williams and Anderson (1991) who separated OCB into two sorts: Citizenship Behaviour towards the Individual (OCBI), and Citizenship Behaviour towards the Organization (OCBO).

Citizenship Behaviour towards the Individual (OCBI): OCBI refers to the processes or behaviour that instantly advantage or merit particular people inside of an organization and thereby contribute indirectly to organizational effectiveness (Lee and Allen, 2002; Williams Anderson (1991).

Citizenship Behaviour towards the Organization (OCBO): Behaviours concerned with profiting the organization in entirety. Examples of such behaviours include conscientiousness, sportsmanship, and civic 
virtue or municipal ideals. This dimension of OCB incorporates behaviours profiting the organization without activities particularly directed towards any organizational member(s) (e.g. adhering to casual guidelines or rules, volunteering for committees).

Occupational stress is a phenomenon depicted as happening when there are discrepancies between the physiological requests inside of a working environment and the powerlessness of employees to adapt to such work requests that are perceived as overwhelming.

Stress as a stimulus is seen as containing the attributes of the environment that are considered irritating and have the impact of bringing about strain reactions in the individual presented to such external features, circumstances or ecological elements. On the contrary, stress as a response for the most part considers stress from an individual's mental reactions to stressors. In this school of thought, early influential scholarship of Selye (1974) characterized stress as "the non-specific response of the body to any demand upon it" and which has a high tendency of disrupting normal homeostatic regulatory physiological functioning of the individual concerned.

Perception involves the process where individuals make meaning of their environment by understanding and managing their sensory impressions. Thus, employees react to stimuli in accordance with what they derive from their sensory impressions. The Perceived Occupational stress refers to the employees' evaluation of the degree to which employees view their workplace as being stressful.

Studies have shown that occupational stress has influence on the task related work behaviour and non-task related work behaviour of employees (Adebiyi, 2013; Colligan, \& Higgins, 2005; Dewe, \& Trenberth, 2004) The influence can be detrimental to the organization as employee productivity levels may reduce and the organizations ability to accomplish its goals. Also many factors (such as job satisfaction, perceived organizational justice, personality traits etc.) have been found to have direct influence on organizational citizenship behaviour.

Empirical studies inquiring into the relationship between occupational stress and organizational citizenship behaviour have found various results. Cropanzano, Howes, Grandey, \& Tooth (1997) found a significant negative relationship between stressful work and organizational citizenship behaviour. Paillé (2010) found no statistically significant relationship between Organizational citizenship Behaviour and Occupational stress.

Thus, this study is aimed at investigating the influence perceived occupational stress has on the organizational Citizenship behaviour of bankers in Ikeja, Lagos state. The following hypotheses were proposed: 
Hypothesis one [H1] states that stress will significantly influence manifestation of Organizational Citizenship Behaviour of bankers

Hypothesis two [H2], states that the occupational stress of bankers in Ikeja will significantly correlate with the Organizational Citizenship behaviour.

Hypothesis Three [H3], states that male bankers will display higher levels of organizational citizenship behaviour than female bankers in commercial banks in Ikeja.

Hypothesis Four [H4], states that older bankers between age 41 and 50 years will display higher levels of organizational citizenship behaviour than younger bankers between 31 and 40 years.

\section{Method}

This study is a non-experimental, quantitative and exploratory research. The total population for this study is all the bankers in Ikeja, Lagos. A simple random sampling technique was used to select a sample of three hundred (300) participants who duly completed the battery of psychological test $(M=135, F=165)$. The battery of psychological instrument consisted of a demographic scale, a Job Stress Scale, and the Organizational Citizenship behaviour Checklist.

Job Stress Scale (JSS) was developed and Standardized by Parker \& Decotiis (1983), to assess the degree to which people perceive their jobs as stressful. The measure uses 13 items to measure job stress along two dimensions. One dimension is time stress (feelings of being under constant pressure) and the second dimension is anxiety (job feelings of anxiety) occupational stress among employees. This was conducted on a five-point Likert-type scale (strongly agree to strongly disagree). (Higher score indicates a higher degree of perceived occupational stress). Job stress was negatively correlated with organizational commitment and job satisfaction and positively correlated with role ambiguity and overload (Jamal \& Baba, 1992).

Organizational Citizenship Behaviour Checklist (OCBC) was developed and standardized by Fox, Spector, Goh, Bruursema, \& Kessler(2012) to assess the frequency of organizational citizenship behaviors performed by employees. Fox et al. (2012) reported internal consistency coefficient alphas for the 20-item version of the OCB-C of .89 and .94 for two self-report samples, and .94 for a co-worker sample. Fox and Spector reported a coefficient alpha of.91 and a concurrent validity of .83 for the scale. The OCB-C uses a 5-point frequency scale (ranging from $1=$ Never to 5 =Everyday). 


\section{Procedure}

The psychological tests were administered to the participants in groups by the researcher after establishing rapport with them. The respondents followed the instruction on the tests to answer the questions.

\section{Data analyses and results}

Responses to the battery of psychological test were entered accordingly into the Statistical Package for the Social Sciences (SPSS) version 20 on a personal computer. Data were coded and analysed using $\mathrm{t}$ independent test and correlation analysis.

Table1: Demographic Characteristics of Respondents

\begin{tabular}{|c|c|c|c|}
\hline \multicolumn{2}{|c|}{ Variables } & F & Percentage \\
\hline \multirow{3}{*}{ Gender } & Male & 135 & $45 \%$ \\
\cline { 2 - 4 } & Female & 165 & $55 \%$ \\
\hline \multirow{3}{*}{ Age } & $21-30$ years & 151 & $50.33 \%$ \\
\cline { 2 - 4 } & $31-40$ years & 97 & $32.33 \%$ \\
\cline { 2 - 4 } & $41-50$ years & 46 & $15.33 \%$ \\
\cline { 2 - 4 } & 51 years Above & 6 & $2 \%$ \\
\hline \multirow{3}{*}{ Educ. Qual. } & BSc & 177 & $59 \%$ \\
\cline { 2 - 4 } & $\mathrm{MSc}$ & 119 & $39.66 \%$ \\
\cline { 2 - 4 } & $\mathrm{PhD}$ & 4 & $1.33 \%$ \\
\hline
\end{tabular}

Table 1 above shows the vivid description of the demographic attributes of the participants who took part in the study. In terms of gender of the respondents, $45 \%$ were males and 55\% were females. Furthermore, the age distribution of the respondents shows that $50.33 \%$ were between ages 21-30; 32.33\% were between ages 31-40; 15.33\% were between ages 41-50 and $2 \%$ were 51 years and above. In terms of educational qualification, 59 $\%$ of the respondents had B.Sc. degree, 39.66\% of the participants had M.Sc. degree, and $1.33 \%$ of the participants had a PhD degree.

\section{Hypothesis Testing}

Hypothesis one (H1) which states that stress will significantly influence manifestation of Organizational Citizenship Behaviour of bankers was tested using the independent sample $\mathrm{t}$-test, the results are as shown below:

Table 2: t-Test analysis showing the differences in Organizational Citizenship Behaviour (OCB) of bankers with different stress levels

\begin{tabular}{|c|c|c|c|c|c|}
\hline $\begin{array}{c}\text { STRESS } \\
\text { LEVELS }\end{array}$ & $\mathrm{N}$ & $\overline{\mathrm{X}}$ & $\mathrm{SD}$ & $\mathrm{T}$ & $\mathrm{P}$ \\
\hline Higher & 132 & 52.55 & 16.73 & 1.233 & $>$ \\
\hline Lower & 168 & 50.18 & 16.19 & .05 \\
\hline
\end{tabular}


Table 2 shows that bank employees with higher stress levels do not manifest lower or higher Organizational Citizenship Behaviour (OCB) levels than the bank employees with lower stress levels. $\left(t=1.233 ; \mathrm{p}^{>} .05\right)$. Thus hypothesis one is rejected.

Hypothesis two (H2) which stated that that the occupational stress of bankers in Ikeja will significantly correlate with the Organizational Citizenship behaviour was tested computing the Pearson's correlation.

Table 3 Correlation analysis for Occupational Stress and OCB

\begin{tabular}{|c|c|c|c|}
\hline VARIABLES & $\mathrm{N}$ & $\mathrm{R}$ & $\mathrm{P}$ \\
\hline OCB & 300 & -.581 & $>.05$ \\
\hline Occupational Stress & & & \\
\hline
\end{tabular}

Table 3 shows that increase or decrease of Organizational Citizenship Behaviour scores will not significantly relate to increase or decrease of Occupational Stress levels and vice-versa. $(\mathrm{r}=-.581 ; \mathrm{p}>.05)$ The hypothesis was therefore rejected.

Hypothesis Three [H3], states that male bankers will display higher levels of organizational citizenship behaviour than female bankers in commercial banks in Ikeja was tested by computing the independent sample t-Test.

Table 4: t-Test analysis for the Organizational Citizenship Behaviour (OCB) scores of male and female bank employees

\begin{tabular}{|c|c|c|c|c|c|}
\hline GENDER & $\mathrm{N}$ & $\overline{\mathrm{X}}$ & $\mathrm{SD}$ & $\mathrm{T}$ & $\mathrm{P}$ \\
\hline MALE & 135 & 50.36 & 17.34 & \multirow{2}{*}{0.275} & \multirow{2}{*}{$>.05$} \\
\hline FEMALE & 165 & 52.45 & 15.80 & & \\
\hline
\end{tabular}

The results mean that the Organizational Citizenship Behaviour (OCB) levels of male bank employees is not different from that of the female bank employees ( $\mathrm{t}=0.275 ; \mathrm{p}>.05)$. The hypothesis was therefore rejected.

Hypothesis Four [H4],which states that older bankers between age 41 and 50 years will display higher levels of organizational citizenship behaviour than younger bankers between 31 and 40 years was tested using the independent sample t-Test.

Table 5: t-Test analysis for the Organizational Citizenship Behaviour (OCB) scores of older and younger bank employees

\begin{tabular}{|c|c|c|c|c|c|}
\hline AGE & $\mathrm{N}$ & $\overline{\mathrm{X}}$ & $\mathrm{SD}$ & $\mathrm{T}$ & $\mathrm{P}$ \\
\hline 31-40 Years & 97 & 49.08 & 13.90 & \multirow{2}{*}{-1.894} & $<.05$ \\
\hline 41-50 Years & 46 & 55.13 & 24.18 & & \\
\hline
\end{tabular}

The results mean that the older bank employees manifest higher Organizational Citizenship Behaviour (OCB) levels than the younger bank employees $(\mathrm{t}=-1.894: \mathrm{p}<.05)$ the hypothesis was therefore accepted. 


\section{Discussion}

Recent years have brought about various researches in the area of organizational citizenship behaviour and occupational stress; however this study explored the influence of occupational stress on organizational citizenship behaviour. Thus four hypotheses were proposed and tested accordingly.

Hypothesis one (H1) which stated that stress will significantly influence manifestation of Organizational Citizenship Behaviour of bankers was not supported. The result can be explained on the basis that organizational citizenship behaviour is a discretionary type of behaviour. Thus, occupational stress is found not to be a significant trigger of organizational citizenship Behaviour of Bankers. This finding agrees with Paillé (2010) who reported that there was no significant relationship between Organizational citizenship Behaviour and Occupational stress.

Hypothesis two (H2) which stated that the occupational stress of bankers in Ikeja will significantly correlate with the Organizational Citizenship behaviour was not supported. This finding contradicts the work of Cropanzano et al., 1997 who claim that perceived Occupational Stress significantly correlates with Organizational Citizenship. The finding from the work of Paillé (2010) corroborates the findings from this study, when he claimed that perceived occupational stress was unrelated to OCB.

Hypothesis three (H3) which states that male bankers will display higher levels of organizational citizenship behaviour than female bankers was not supported. This finding could be due to the fact that organizational citizenship behaviour is a helping behaviour and not a gender trait. The result from this research is consistent with the results from the work of Uzonwanne (2014). Uzonwanne (2014) concluded that no significant difference was found between the organizational citizenship behaviour levels of male and female bank employees.

Hypothesis Four (H4) which states that older bankers between age 41 and 50 years will display higher levels of organizational citizenship behaviour than younger bankers between 31 and 40 years was supported. The outcome of the result can be linked to the fact the most components of Organizational citizenship Behaviour thrives on maturity of individuals. However, the result is in contrasts with Uzonwanne (2014), that concluded that there was no statistically reliable difference between OCB and demographic variables such as age sex and marital status.

\section{Conclusion}

This study has revealed that Organizational citizenship behaviour which is a discretionary type of behaviour that is not influenced by occupational stress nor gender of the employees. Thus, predicting helping 
behaviour such as organizational citizenship behaviour may be associated with multiple variables.

Furthermore, this study revealed that older bankers between age 41 and 50 years display higher levels of organizational citizenship behaviour than younger bankers between 31 and 40 years. Thus, bank executives should use this information in their allocation of duties to work groups, as older bank employees within ages 41 and 50 are more capable of exhibiting OCB than younger bankers. The former, are in better positions to occupy positions in which organizational citizenship behaviours such as Altruistic behaviours are needed. An example may be the customer care unit where the customers are seeking help from the bankers on several issues.

The implications of these findings substantiate the importance of having organizational psychologists in banks to assess and enhance variables that can promote helping behaviours which is the key to better work outcomes and accomplishment of organizational objectives.

Finally, this research finding noted that gender differences should not be part of the criteria for promotion to positions where character traits of helping behaviours such as OCB is needed.

\section{Limitations of the study and suggestion for future research}

This research is not without limitations first this study adopted survey research methods which is sometimes characterized with response biases. Second, the sample size may not be adequate to generalize the findings to the entire populations of bankers in Nigeria.

However, it is suggested that future research should consider experimentation method and focus group discussion to establish cause-effect relationships between the variables of interest.

\section{References:}

Adebiyi, D. R (2013). Occupational Stress Among Academic Staff Of Ekiti State University, Ado-Ekiti. European Scientific Journal vol.9,.4, 202-208.

Bateman, T. S., \& Organ, D. W. 1983. Job satisfaction and the good soldier: The relationship between affect and employee "citizenship." Academy of Management Journal, 26: 587-595

Borman, W. C., \& Motowidlo, S. J. 1993. Expanding the criterion domain to include elements of contextual performance. In N. Schmitt, W. C. Borman, \& Associates (Eds.), Personnel selection in organizations: 71-98. San Francisco, CA: Jossey-Bass.

Colligan, T. W. \& Higgins, E. M. (2005). Workplace stress: Etiology and consequences. Journal of Workplace Health, 21, 2, pp. 90-97 
Cooper, C. L. \& Cartwright, S. (1997). An intervention strategy for workplace stress. Journal of Psychosomatic Research, 43, 1, pp. 7-16.

Cropanzano,R., Howes,J.C., Grandey, A. A.,\& Tooth, P. (1997). The relationship of organizational politics and support to work behaviours, attitudes and stress. Journal of Organizational Behaviour, 18,159-180.

Dewe, P. \& Trenberth, L. (2004). Work stress and coping: Drawing together theory and practice. British Journal of Guidance and Counselling, 32, pp. 143-156.

Dillard, J.P. \& Fritz, J. (1995). Interpersonal relationships and organizational performance. Paper presented at Annual Convention of the Western Speech Communication Association, Portland, OR.

Fox, S., Spector, P. E., Goh, A., Bruursema, K., \& Kessler, S. R. (2012). The deviant citizen: Measuring potential positive relations between counterproductive work behavior and organizational citizenship behavior. Journal of Occupational and Organizational Psychology, 85, 199-220.

George, J. M., \& Brief, A. P. 1992. Feeling good-doing good: A conceptual analysis of the mood at work-organizational spontaneity relationship. Psychological Bulletin, 112: 310-329.

George, J. M., \& Jones, G. R. 1997. Organizational spontaneity in context. Human Performance, 10: 153-170.

Greenhaus, J. H., \& Beutell, N. J. (1985). Sources of conflict between work and family roles. Academy of Management Review, 10, 76-88.

Hackman, J. R. \& Oldham, G. R. (1980). Work redesign. Readings, MA: Addison-Wesley.

Jamal, M. \& Baba, V. V. (1992) Shiftwork and department-type related to job stress, work attitudes and behavioral intentions: A study of nurses. Journal of Organizational Behavior.Vol. 13, 5, 449-464

Law, S.K., Wong, C, \& Chen, X.Z.(2005). The construct of organizational citizenship behaviour: should we analyse after we have conceptualized? In D.L. Turnispeed (Ed.), Handbook of organizational citizenship behaviour (pp. 47-65). New York;:ova Science Publishers.

Lee, K., \& Allen, N. J. (2002). Organizational citizenship behaviour and workplace deviance: The role of affect and cognitions. Journal of Applied Psychology, 87(1), 131-142.

Organ, D. W. (1983). Job satisfaction and the good soldier: the relationship between affect and employee citizenship. Academy of Management Journal, 26, 587- 595 .

Organ, D. W. (1988). Organizational citizenship behavior: The good soldier syndrome. Lexington, MA: Lexington Books.

Organ, D. W. (1990). The motivational basis of organizational citizenship behavior, In B. M. Staw, \& L. L. Cummings (Eds.), Research in Organizational Behavior, 12, (pp. 43-72). Greenwich, CT: JAI Press. 
Organ, D. W. (1997). Organizational citizenship behavior: It's construct clean-up time.m Human Performance, 10, 85-97.

Organ, D. W., \& Konosvky, M. (1989). Cognitive versus affective determinants of organizational citizenship behavior. Journal of Applied Psychology, 74, 157- 164.

Paillé, P. (2010). Citizenship in the workplace: examining work attitudes as predictors among French employees. International Journal of Business and Management, 5.4., 53-64.

Parker, D. F., \& Decotiis, T.A (1983). Organizational determinants of job stress. Organizational Behaviour and Human Performance, 32, 160-177.

Penner, L. A., Midili, A. R., \& Kegelmeyer, J. (1997). Beyond job attitudes: a personality and social psychology perspective on the causes of organizational citizenship behavior, Human Performance, 10(2), 111-131.

Podsakoff, P., Ahearne, M., \& MacKenzie, S. (1997). Organizational citizenship behavior and the quantity and quality of work group performance. Journal of Applied Psychology.82(2):262270,doi:10.1037/00219010.82.2.262,http://dx.doi.org/1 0.1037/0021-9010.82.2.262

Podsakoff, P., MacKenzie, S (1989). A second generation measure of organizational behavior. Unpublished manuscript. Indiana University. Bloomington.

Podsakoff, P., MacKenzie, S., Moorman, R., \& Fetter, R. (1990). Transformational leader behaviors and their effects on followers' trust in leader, satisfaction, and organizational citizenship behaviors. Leadership Quarterly. 1(7): 107-142, doi:10.1016/1048-9843(90)90009-7,

Podsakoff, P. M., MacKenzie, S. B., Paine, J. B., \& Bachrach, D. G. (2000). Organization citizenship behaviors: a critical review of the theoretical and empirical literature and suggestions for future research. Journal of Management, 26, 513-563.

Selye H. (1974). Stress without Distress. New American Library: New York. Uzonwanne, F. C(2014).Organizational citizenship behaviour and demographic factors among oil workers in Nigeria. IOSR Journal of Humanities and Social Sciences, 19(8) PP87-95.

Williams, L. J., \& Anderson, S. E. (1991). Job satisfaction and organizational commitment as predictors of organizational citizenship and in-role behaviors. Journal of Management, 17, 601-617. 